\title{
Role of BDNF and neurotrophic receptors in human inner ear development
}

\author{
L. Johnson Chacko ${ }^{1}$ - M. J. F. Blumer ${ }^{2}$ - E. Pechriggl ${ }^{2}$ - H. Rask-Andersen ${ }^{3}$ - W. Dietl $^{1}$ \\ A. Haim ${ }^{4}$ - H. Fritsch ${ }^{2}$ R. Rlueckert ${ }^{1,5}$ - J. Dudas ${ }^{1}$ - A. Schrott-Fischer ${ }^{1}$ (D)
}

Received: 7 March 2017 / Accepted: 25 August 2017 /Published online: 19 September 2017

(C) The Author(s) 2017. This article is an open access publication

\begin{abstract}
The expression patterns of the neurotrophin, brain-derived neurotrophic factor, BDNF, and the neurotrophic receptors-p75NTR and Trk receptors-in the developing human fetal inner ear between the gestational weeks (GW) 9 to 12 are examined via in situ hybridization and immunohistochemistry. BDNF mRNA expression was highest in the cochlea at GW 9 but declined in the course of development. In contrast to embryonic murine specimens, a decline in BDNF expression from the apical to the basal turn of the cochlea could not be observed. p75NTR immunostaining was most prominent in the nerve fibers that penetrate into
\end{abstract}

J. Dudas

Jozsef.Dudas@i-med.ac.at

1 Department of Otorhinolaryngology, Medical University of Innsbruck, Anichstr. 35, 6020 Innsbruck, Austria

2 Department of Anatomy, Histology \& Embryology, Division of Clinical \& Functional Anatomy, Medical University of Innsbruck, Muellerstrasse 59, 6020 Innsbruck, Austria

3 Department of Surgical Sciences, Head and Neck Surgery, Section of Otolaryngology, Uppsala University Hospital, 75185 Uppsala, SE, Sweden

4 Department for Plastic, Reconstructive \& Aesthetic Surgery, Medical University of Innsbruck, Innerkoflerstrasse 1, 6020 Innsbruck, Tirol, Austria

5 University Clinics Innsbruck, Tirol Kliniken, Anichstr. 35, 6020 Innsbruck, Austria the sensory epithelia of the cochlea, the urticule and the saccule as gestational age progresses. TrkB and TrkC expression intensified towards $\mathrm{GW} 12$, at which point the BDNF mRNA localization was at its lowest. TrkA expression was limited to fiber subpopulations of the facial nerve at GW 10. In the adult human inner ear, we observed BDNF mRNA expression in the apical poles of the cochlear hair cells and supporting cells, while in the adult human utricle, the expression was localized in the vestibular hair cells. We demonstrate the highly specific staining patterns of BDNF mRNA and its putative receptors over a developmental period in which multiple hearing disorders are manifested. Our findings suggest that BDNF and neurotrophin receptors are important players during early human inner ear development. In particular, they seem to be important for the survival of the afferent sensory neurons.

Keywords Inner ear $\cdot$ Human $\cdot$ BDNF $\cdot$ Neurotrophin receptors $\cdot$ In situ hybridization

\section{Introduction}

In vertebrates, the inner ear is the innermost part of the ear, comprising the cochlea and the vestibular organ, serving hearing and balance functions, respectively. Both sensory organs have several specialized cell types and use the same kind of detection cells, namely hair cells, to send information via a group of nerve cells 
(spiral ganglion of the cochlea and vestibular ganglion of the vestibular organ) to the brain. The inner ear is formed during embryonic development and the expression of specific proteins governs the maturation and function of the organ and its specialized cell types (Wu and Kelley 2012). In humans, the inner ear develops during the fourth embryonic week from the pre-placode region (Whitfield 2015).

Animal studies on inner ear formation provide useful information on which molecular pathways are needed to regulate hair cells development and their innervation and thus may be helpful for treating inner ear diseases. For instance, studies on mutant mouse have demonstrated that the loss of BDNF and its receptor TrkB results in a complete loss of the afferent innervation of the semi-circular canal. Furthermore, a reduction in innervation along the tonotopic axis of the cochlea has been observed (Fritzsch et al. 1997b, 2004). In late post-natal stages of these mutant mice, a lack of afferent innervation in the apical part of the cochlea has been shown, while the basal portion was unaffected but in older stages, the opposite was true. The reshaping of innervation was probably regulated by autocrine signaling between neurotrophins and their receptors in cochlear neurons (Schimmang, et al. 2003). Embryonic inner ear developmental in chick (Hallbook and Fritzsch 1997) and murines (Ernfors et al. 1994) has also revealed the biological significance of BDNF expression for both afferent and efferent fiber innervation. Interestingly, later research has suggested that both modes of nervous outgrowth are independent of BDNF and its receptor in the vestibulum (Bianchi et al. 1996; Ernfors et al. 1995). BDNF also promotes neuronal survival and neurite sprouting in early post-natal rat vestibular ganglion neurons (Inoue et al. 2014). Furthermore, vestibular ganglia repair and neurite outgrowth towards hair cells after ototoxic damage in chinchillas was also regulated by BDNF, while TrkB levels remained unchanged (Popper et al. 1999). In patients with hearing loss, BDNF gene therapy treatment has been shown to override the genetic defect, leading to a new formation of the auditory neurons with a pronounced neural sprouting into the auditory epithelium despite missing hair cells. The effect of regenerative sprouting may influence a better outcome of cochlear implantation (Fukui, et al. 2012).

Apart from the important function of BDNF, the deletion of NT-3 and its receptor TrkC has also resulted in a loss of spiral ganglion innervation along the basal turn of the cochlea (Fritzsch et al. 1997a). Moreover, in double knock-out mice lacking BDNF and NT-3 or TrkB and TrkC, a complete loss of afferent innervation of the inner ear was noted (Fritzsch et al. 1999). In the vestibular system, TrkB or TrkC
Table 1 Gestational specimens and cochlea sections used in the in situ hybridization quantification study

\begin{tabular}{llllll}
\hline $\begin{array}{l}\text { Gestational } \\
\text { age }\end{array}$ & $\begin{array}{l}\text { Specimen } \\
\text { no. }\end{array}$ & Riboprobe & $\begin{array}{l}\text { Apical } \\
\text { turn }\end{array}$ & $\begin{array}{l}\text { Middle } \\
\text { turn }\end{array}$ & $\begin{array}{l}\text { Basal } \\
\text { turn }\end{array}$ \\
\hline GW 9 & 2 & Antisense & 6 & 6 & 6 \\
& & Sense & 4 & 4 & 6 \\
GW 10-11 & 4 & Antisense & 6 & 15 & 9 \\
& & Sense & 6 & 14 & 8 \\
GW 12 & 3 & Antisense & 1 & 4 & 8 \\
& & Sense & 1 & 4 & 6 \\
\hline
\end{tabular}

activation was sufficient to promote vestibular ganglion neuron survival while TrkB activation was required to promote proper innervation and synaptogenesis (Agerman et al. 2003). Elevated TrkB and TrkC receptor gene expression were observed both prior to and after the onset of hearing in the post-natal murine inner ear (Bitsche et al. 2011).

In the adult human inner ear, the expression of p75NTR was identified in the glial cells including Schwann cells and satellite glial cells in the Rosenthal canal, in the central nerve bundles within the modiolus and in the osseous spiral lamina of the human cochleae (Liu et al. 2011). However, the role of this receptor during human inner ear development is still a matter of discussion.

Examination of the human fetal cochleo-vestibular ganglions using immunocytochemistry (Vega et al. 1999) revealed that neurotrophic receptor expression was initiated from gestational week (GW) 5 onwards, with the TrkA receptor expression decreasing after GW 9. However, the expression of TrkB and TrkC peaked between GW 8 and 12. p75NTR expression remained more or less stable throughout development (Vazquez et al. 1996). This unique pattern of receptor expression was accompanied by specific developmental events like sensory neuronal innervation as well as target-dependent cell death (Vega et al. 1999). These studies (Vazquez et al. 1996; Vega et al. 1999) used western blots and immunocytochemistry to identify neurotrophin receptor expression but only in the dissected fetal cochleo-

Table 2 In situ hybridization probes

\begin{tabular}{llllc}
\hline $\begin{array}{l}\text { Gene } \\
\text { name }\end{array}$ & $\begin{array}{l}\text { Accession } \\
\text { no. }\end{array}$ & $\begin{array}{l}\text { Sense } \\
\text { oligonucleotide } \\
\text { probe }\end{array}$ & $\begin{array}{l}\text { Antisense } \\
\text { oligonucleotide } \\
\text { probe }\end{array}$ & Length \\
\hline BDNF & $\begin{array}{c}\mathrm{NM}_{\overline{7}} \\
170735\end{array}$ & $1247-1780$ & $1247-1780$ & $\begin{array}{c}533 \\
\text { bases }\end{array}$ \\
\hline
\end{tabular}


Table 3 Sense and anti-sense primer sequences for BDNF in in situ hybridization probes

\section{BDNF Sense sequence}

\begin{tabular}{|c|c|c|}
\hline $\begin{array}{l}\text { Query } \\
60\end{array}$ & 1 & AGCTGTTGGATGAGGACCAGAAAGTTCGGCCCAATGAAGAAAACAATAAGGACGCAGACT \\
\hline $\begin{array}{l}\text { Sbjct } \\
1350\end{array}$ & 1291 & AGCTGTTGGATGAGGACCAGAAAGTTCGGCCCAATGAAGAAAACAATAAGGACGCAGACT \\
\hline $\begin{array}{l}\text { Query } \\
120\end{array}$ & 61 & |||||||||||||||||||||||||||||||||||||||||||||||||||||||||| \\
\hline $\begin{array}{l}\text { Sbjet } \\
1410\end{array}$ & 1351 & TGTACACGTCCAGGGTGATGCTCAGTAGTCAAGTGCCTTTGGAGCCTCCTCTTCTCTTTC \\
\hline $\begin{array}{l}\text { Query } \\
180\end{array}$ & 121 & TGCTGGAGGAATACAAAAATTACCTAGATGCTGCAAACATGTCCATGAGGGTCCGGCGCC \\
\hline $\begin{array}{l}\text { Sbjet } \\
1470\end{array}$ & 1411 & TGCTGGAGGAATACAAAAATTACCTAGATGCTGCAAACATGTCCATGAGGGTCCGGCGCC \\
\hline $\begin{array}{l}\text { Query } \\
240\end{array}$ & 181 & АСTCTGACCCTGCCCGCCGAGGGGAGCTGAGCGTGTGTGACAGTATTAGTGAGTGGGTAA \\
\hline $\begin{array}{l}\text { Sbjet } \\
1530\end{array}$ & 1471 & ACTCTGACCCTGCCCGCCGAGGGGAGCTGAGCGTGTGTGACAGTATTAGTGAGTGGGTAA \\
\hline $\begin{array}{l}\text { Query } \\
300\end{array}$ & 241 & CGGCGGCAGACAAAAAGACTGCAGTGGACATGTCGGGCGGGACGGTCACAGTCCTTGAAA \\
\hline $\begin{array}{l}\text { Sbjct } \\
1590\end{array}$ & 1531 & CGGCGGCAGACAAAAAGACTGCAGTGGACATGTCGGGCGGGACGGTCACAGTCCTTGAAA \\
\hline $\begin{array}{l}\text { Query } \\
360\end{array}$ & 301 & AGGTCCCTGTATCAAAAGGCCAACTGAAGCAATACTTCTACNAGACCAAGTGCAATCCCA \\
\hline $\begin{array}{l}\text { Sbjct } \\
1650\end{array}$ & 1591 & AGGTCCCTGTATCAAAAGGCCAACTGAAGCAATACTTCTACGAGACCAAGTGCAATCCCA \\
\hline $\begin{array}{l}\text { Query } \\
420\end{array}$ & 361 & TGGGTTACACAAAAGAAGGCTGCAGGGGCATAGACAAAAGGCATTGGAACTCCCAGTGCC \\
\hline $\begin{array}{l}\text { Sbjet } \\
1710\end{array}$ & 1651 & $\begin{array}{l}\|\|\|\| \\
\text { TGGGTTACACAAAAGAAGGCTGCAGGGGCATAGACAAAAGGCATTGGAACTCCCAGTGCC }\end{array}$ \\
\hline $\begin{array}{l}\text { Query } \\
480\end{array}$ & 421 & GAACTACCCAGTCGTACGTGCGGGCCCTTACCATGGATAGCAAAAAGAGAATTGGCTGGC \\
\hline $\begin{array}{l}\text { Sbjet } \\
1770\end{array}$ & 1711 & ACTACCCAGTCGTACGTGCGGGCCCTTACCATGGATAGCAAAAAGAGAATTGGCTGGC \\
\hline
\end{tabular}

\section{BDNF Anti-sense sequence}

Query 1 TATCCATGGTAAGGGCCCGCACGTACGACTGGGTAGTTCGGCACTGGGAGTTCCAATGCC 60 


\begin{tabular}{|c|c|c|}
\hline $\begin{array}{l}\text { Sbjet } \\
1690\end{array}$ & 1749 & TATCCATGGTAAGGGCCCGCACGTACGACTGGGTAGTTCGGCACTGGGAGTTCCAATGCC \\
\hline $\begin{array}{l}\text { Query } \\
120\end{array}$ & 61 & TTTTGTCTATGCCCCTGCAGCCTTCTTTTGTGTAACCCATGGGATTGCACTTGGTCTCGT \\
\hline $\begin{array}{l}\text { Sbjet } \\
1630\end{array}$ & 1689 & TTTTGTCTATGCCCCTGCAGCCTTCTTTTGTGTAACCCATGGGATTGCACTTGGTCTCGT \\
\hline $\begin{array}{l}\text { Query } \\
180\end{array}$ & 121 & ANAAGTATTGCTTCAGTTGGCCTTTTGATACAGGGACCTTTTCAAGGACTGTGACCGTCC \\
\hline $\begin{array}{l}\text { Sbjet } \\
1570\end{array}$ & 1629 & AGAAGTATTGCTTCAGTTGGCCTTTTGATACAGGGACCTTTTCAAGGACTGTGACCGTCC \\
\hline $\begin{array}{l}\text { Query } \\
240\end{array}$ & 181 & CGCCCGACATGTCCACTGCAGTCTTTTTGTCTGCCGCCGTTACCCACTCACTAATACTGT \\
\hline $\begin{array}{l}\text { Sbjet } \\
1510\end{array}$ & 1569 & $\begin{array}{l}|||||||||||||||||||||||||||||||||||||||||||||||||||||||||||||||||| \mid \\
\text { CGCCCGACATGTCCACTGCAGTCTTTTTGTCTGCCGCCGTTACCCACTCACTAATACTGT }\end{array}$ \\
\hline $\begin{array}{l}\text { Query } \\
300\end{array}$ & 241 & CACACACGCTCAGCTCCCCTCGGCGGGCAGGGTCANAGTGGCGCCGGACCCTCATGGACA \\
\hline $\begin{array}{l}\text { Sbjet } \\
1450\end{array}$ & 1509 & CACACACGCTCAGCTCCCCTCGGCGGGCAGGGTCAGAGTGGCGCCGGACCCTCATGGACA \\
\hline $\begin{array}{l}\text { Query } \\
360\end{array}$ & 301 & TGTTTGCAGCATCTAGGTAATTTTTGTATTCCTCCAGCANAAAGAGAANAGGAGGCTCCA \\
\hline $\begin{array}{l}\text { Sbjet } \\
1390\end{array}$ & 1449 & 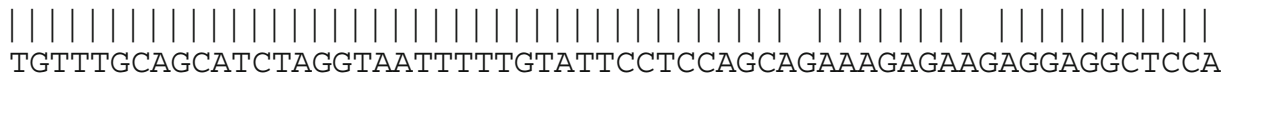 \\
\hline $\begin{array}{l}\text { Query } \\
420\end{array}$ & 361 & AAGGCACTTGACTACTGAGCATCACCCTGGACGTGTACAAGTCTGCGTCCTTATTGTTTT \\
\hline $\begin{array}{l}\text { Sbjet } \\
1330\end{array}$ & 1389 & 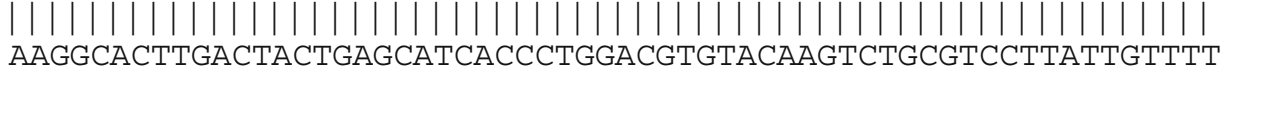 \\
\hline Query & 421 & 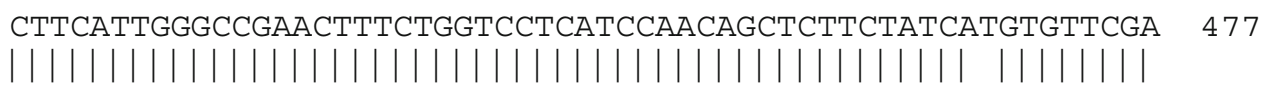 \\
\hline Sbjet & 1329 & CTTCATTGGGCCGAACTTTCTGGTCCTCATCCAACAGCTCTTCTATCACGTGTTCGA \\
\hline
\end{tabular}


vestibular ganglion. Unfortunately, data from the cochlea and vestibulum are not available down to the present day.

The present study focused on the role of BDNF, p75NTR, TrkA, TrkB and TrkC neurotrophic receptors during human inner ear development. We investigated samples from GW 9-12 and examined the entire inner ear including the cochlea and the vestibulum using in situ hybridization (ISH) and immunohistochemistry (IHC). The results enhance our understanding of those genes and molecules important for human inner ear development.

\section{Materials and methods}

\section{Embryonic fetal specimens (Table 1)}

Nine human embryos (2 GW 9; 3 GW 10, 1 GW 11; 3 GW 12) corresponding to the gestational weeks 9-12 were obtained with prior parental approval after legally permitted abortions performed in accordance with Austrian legislation ( $\$ 97 \mathrm{StGB}$ ). Fetal specimens belonging to GW 9-12 are the only developmental stages legally permitted to be acquired. The utilized specimens were certified by embryologists to exhibit no macroscopic malformations and their embryological ages were differentiated by quantification of features like crownrump length, external and internal morphology and the estimated gynecological age. This research was approved by the Ethics Commission of the University Clinic for Gynecology and Obstetrics at the Medical University of Innsbruck, ethical approval number AN2014-0095 335/4.11.

Tissue preparation for histology, immunohistochemistry and in situ hybridization on paraffin sections

Temporal bone specimens were excised immediately following abortions and then fixed by immersion in a solution of $4 \%$ paraformaldehyde in phosphate-buffered saline (PBS, $0.1 \mathrm{M}$ ) at $\mathrm{pH} 7.4$ overnight. They were then rinsed in PBS, dehydrated and embedded in paraffin, utilizing a histological infiltration processor (Miles Scientific, Naperville, IL, USA). The embedded specimens were serially sectioned at $4 \mu \mathrm{m}$ thickness using a HM 355S microtome (Microm, Walldorf, Germany) and mounted onto Superfrost ${ }^{\mathrm{TM}}$ Plus slides (Menzel, Braunschweig, Germany). The sections were then dried overnight at room temperature, following which the slides were incubated at $60^{\circ} \mathrm{C}$ for $2 \mathrm{~h}$ to enable the sections to adhere firmly to the glass surface. Every 
tenth section was stained with hematoxylin/eosin (Shandon Varistain 24-4; Histocom, Vienna, Austria).

\section{In situ hybridization (ISH) (Tables 2, 3)}

Human BDNF-specific riboprobes were synthesized using the following primers: forward: GGCTGACA CTTTCGAACACA; reverse: CTTATGAATCGCCA GCCAAT. The DNA product was 519 base pairs long and was synthesized using Go-Taq Green Master Mix (Promega, Madison, WI, USA) and cDNA reversetranscribed from mRNA isolated from human gingiva fibroblast cell line (Cell Lines Service, Heidelberg, Germany). For the polymerase chain reaction (PCR), a reaction-annealing temperature of $60{ }^{\circ} \mathrm{C}$ was used and the instructions of Promega were followed.

For the production of the riboprobes, the $\mathrm{T} 7$ polymerase promoter sequence (5'-TAATACGACTCACTATAGGG AGA-3') was added to the forward or the reverse primers and PCR products containing the $\mathrm{T} 7$ sequence before the forward and before the reverse primer sequences were synthesized under the same conditions as above. Then, $200 \mathrm{ng}$ PCR products were Sanger-sequenced by Microsynth (Vienna, Austria) using $\mathrm{T} 7$ promoter and the identification and orientation of the sequence following the T7 promoter were controlled using a NCBI Blast (NIH, Bethesda, MD, USA) nucleotide sequence alignment tool. The antisense and sense orientations of the sequence following the $\mathrm{T} 7$ promoter were confirmed. Sense and antisense riboprobes were synthesized and digoxigenin (DIG) labeled using the T7 in vitro transcription kit of Roche Life Sciences (Cat. No. 11175025910; Roche, Mannheim, Germany) and $1 \mu \mathrm{g}$ of template PCR products.

The DIG labeling and the riboprobe concentration were determined using the DIG luminescent detection kit (Cat. No. 11,363,514,910; Roche) and CDP-star substrate (Roche) following the instruction of the manufacturer. In situ hybridization was performed on $5-\mu \mathrm{m}$ paraffin sections in a Ventana Discovery Classic immunostainer (Tucson, AZ, USA) using the Ribomap kit and Bluemap kit (Ventana). For antigen retrieval, a CC1 buffer (mild) and Protease 3 (16 min) were used. Next, $200 \mathrm{ng} / \mathrm{ml}$ DIG-labeled riboprobe and unlabeled $160 \mu \mathrm{g} / \mathrm{ml}$ sheared salmon sperm DNA (Ambion; Fisher Scientific, Vienna, Austria) were added to $100 \mu l$ Ribohybe (Ventana) on each slide. The probe hybridization was performed at $66{ }^{\circ} \mathrm{C}$ for $3 \mathrm{~h}$ and $2 \times$ SCC washes, $3 \times 8 \mathrm{~min}$, were carried out at $70{ }^{\circ} \mathrm{C}$, as suggested by DIG In situ Application Note No. 1 (Roche Diagnostics, Mannheim, Germany, 2012).
Fig. 1 Sections of the developing inner ear from GW 9 to 12 hybridized with antisense and sense probes specific for BDNF. a Horizontal section plane of the fetal cochlea at GW 9 hybridized with the anti-sense probe showing elevated BDNF mRNA expression (blue) in the cochlear duct (asterisks) and the vestibular ganglion ( $v g$ ). Elevated expression is also apparent in the fetal crista ampullaris (arrow). $\mathbf{c}$ BDNF expression in the cochlea at GW 10. Intense expression is seen in the developing spiral ganglia (spg) (Fig. 1c inset) as well as the apical (at) and basal (bt) turns. e Expression of BDNF is apparent in the extra-striolar portions of the saccule (arrows) as well as the cuboidal epithelium (ce) at GW 12 but no expression is found in the striolar region. $\mathrm{g}$ BDNF expression is present in the supporting cells of the basal (arrow, bt) and lower basal turns (arrow, $l b t)$ of the cochlea at GW 12. The inset shows a higher magnification of the basal turn. Note that only the supporting cells are labeled. Residual BDNF expression is also apparent in the extra-striolar region of the utricle (u). Note that from GW 9 to 12 , the staining intensity for BDNF declines. $\mathbf{b}, \mathbf{d}, \mathbf{f}, \mathbf{h}$ In the control sections, only nuclear fast red counterstaining was observed. Scale bar (a-d, g, h) $30 \mu \mathrm{m},(\mathbf{c}, \mathbf{g}, \mathbf{h}$, insets) $2.5 \mu \mathrm{m},(\mathbf{e}, \mathbf{f})$ $10 \mu \mathrm{m}$. otc otic capsule

The hybridization signal was detected by anti-DIG Fab fragments (alkaline phosphatase coupled) purchased from Roche and by the Bluemap kit (Roche, Ventana) as instructed by the providers. The BCIP/NBT (5Bromo-4-chloro-3-indolyl phosphate/Nitro blue tetrazolium) substrate time was $1.5-3 \mathrm{~h}$. The cell nuclei were counterstained in red by Red Counterstain II (Ventana). Antisense riboprobes displayed a specific reaction, while the sense probe did not react.

\section{Antisera for immunohistochemistry (IHC) (Table 4)}

The hosts, dilutions and sources of primary antibodies utilized are listed in the Table.

Immunohistochemistry was performed utilizing a Ventana Roche ${ }^{\circledR}$ Discovery XT Immunostainer, applying a DAB-MAP discovery research standard procedure. When required, antigen retrieval was performed by epitope unmasking via a heat induction methodology performed while the sections were immersed in EDTA buffer (Cell Conditioning Solution CC1; Ventana 950124).

The sections were incubated with the appropriate primary antibodies at $37{ }^{\circ} \mathrm{C}$ for $1 \mathrm{~h}$ and then with the Discovery Universal Secondary Antibody (Ventana 760-4250) at room temperature for $30 \mathrm{~min}$. Antibody detection was then attained employing the DAB-MAP Detection Kit (Ventana 760-124) utilizing a combinatorial approach involving the diaminobenzidine (DAB) development method with copper enhancement followed by counterstaining with hematoxylin (Ventana 760-2021) for 


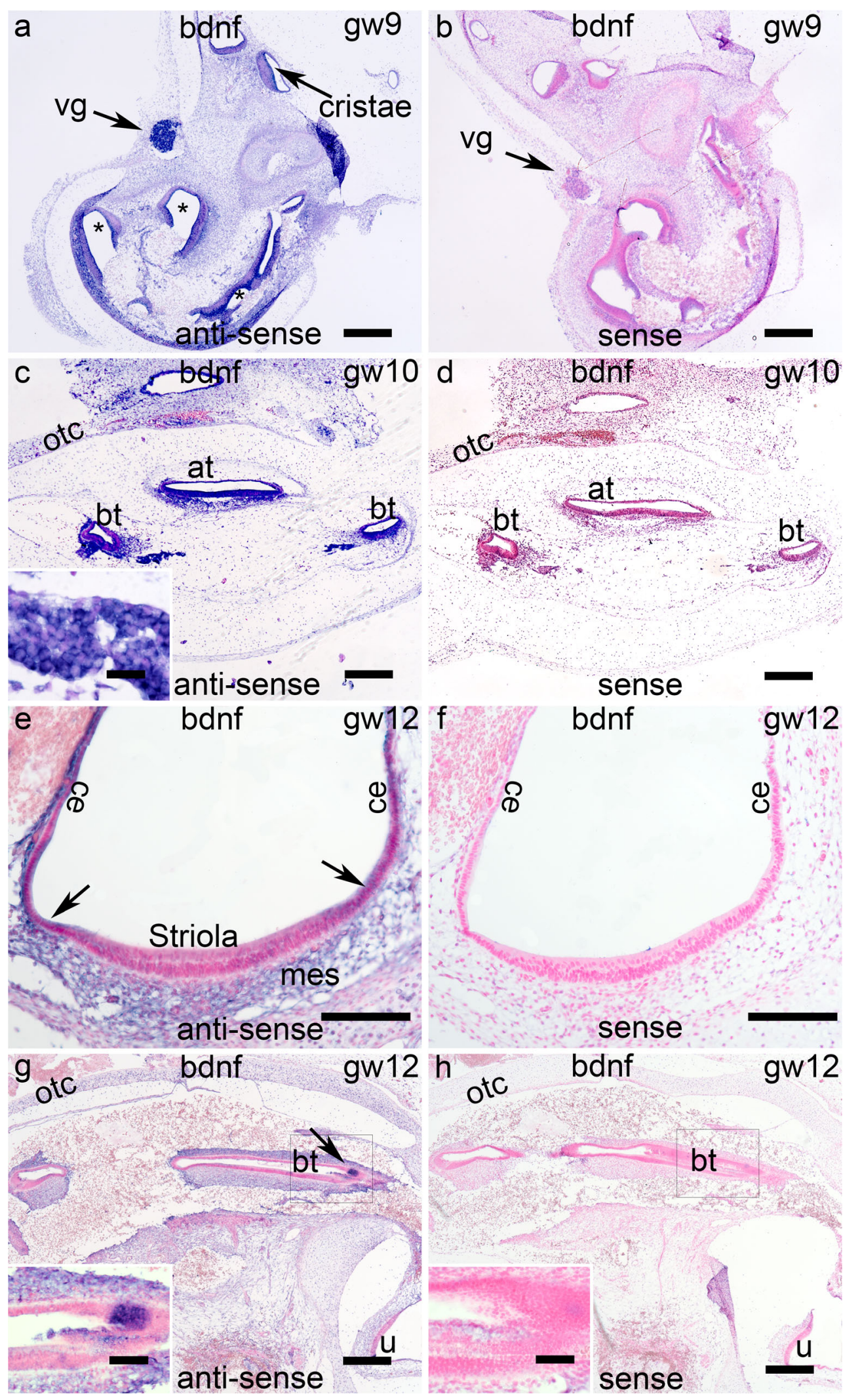




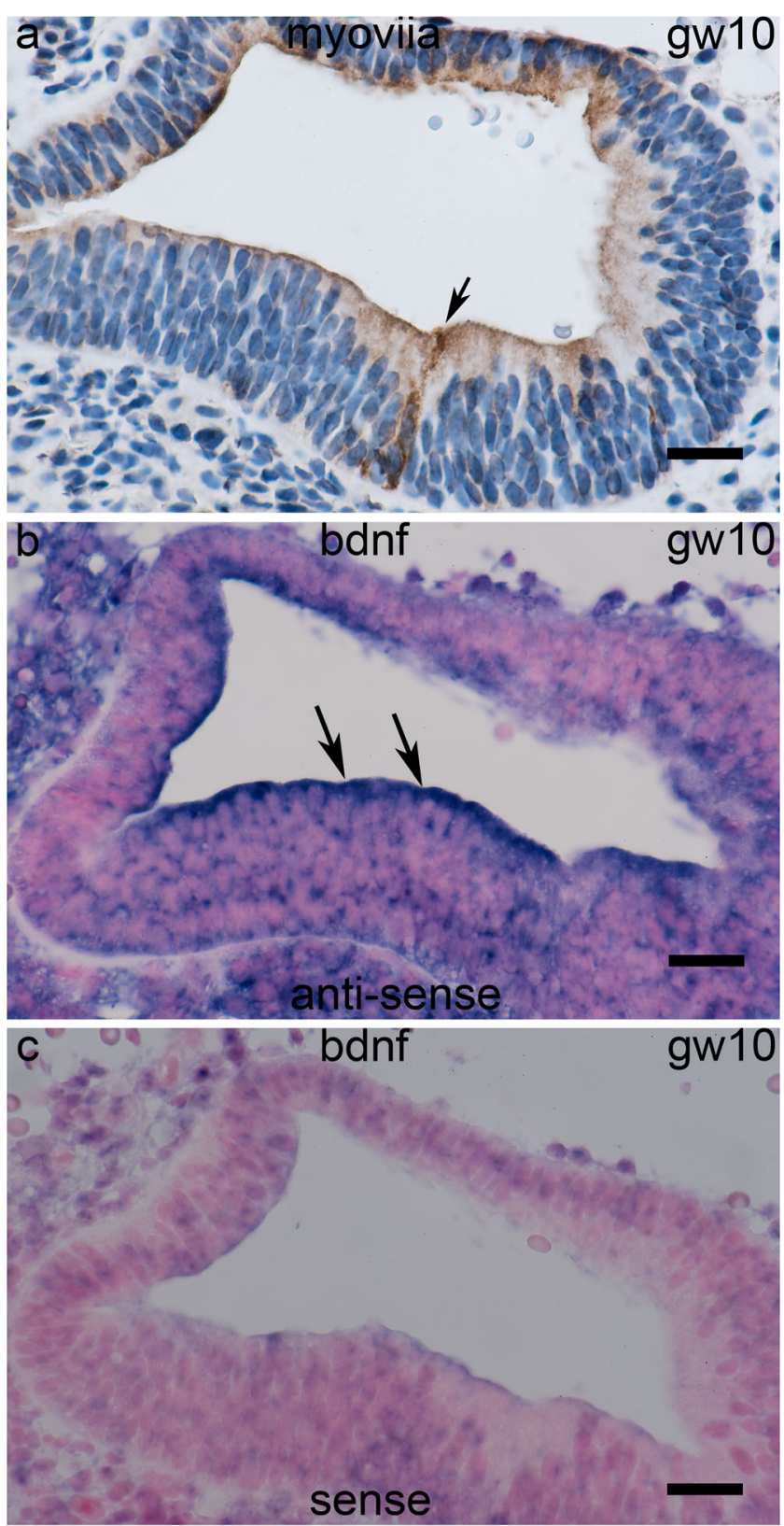

Fig. 2 Adjacent sections of the inner ear at GW 10. a Myosin VIIA immune staining (brown) reveals one cochlear hair cell starting to develop (arrow points to the hair cell). The section is counterstained with hematoxylin. b BDNF expression is apparent (blue) in the apical portion of the cells (arrows). c In the control sections, only nuclear fast red counterstaining was observed. Scale bar (a-c) $2 \mu \mathrm{m}$

$4 \mathrm{~min}$. The stained sections were then dehydrated using an upgraded alcohol series, clarified with xylene and mounted permanently with Entellan ${ }^{\circledR}$ (Merck, Darmstadt, Germany).

Positive controls (e.g., small intestine, brain and pancreas) were supplemented for each experiment. Negative controls were acquired by alternating the primary antibodies with reaction buffer or substituting them with isotype-matching immunoglobulins. These controls never yielded any immunostaining.

\section{Fluorescence ISH (FISH) and IHC}

The FISH protocol prescribed by Ventana was utilized with all parameters matching those described above. The protocol was preprogrammed on Ventana Discovery with both primary and secondary antibodies incubated for $1 \mathrm{~h}$. The secondary antibody Alexa Fluor ${ }^{\circledR}$ 488 (ThermoFisher Scientific \#A-21206) was used for IHC and DyLight ${ }^{\circledR 594}$ anti-digoxigenin/digoxin (Vector Laboratories \#DI-7594) for ISH.

\section{Image analysis of the sections}

All sections were digitally examined using Zeiss AxioVision 4.1 microscope software coupled to an AxioCam HRc color camera and an AxioPlan2 microscope (Zeiss, Jena, Germany).

The in situ probe localized sections were analyzed at $\times 20$ magnification utilizing a TissueFaxs Plus System coupled onto a Zeiss ${ }^{\circledR}$ Axio Imager Z2 Microscope. Analyzed sections were then acquired using the TissueFaxs (TissueGnostics ${ }^{\circledR}$, Vienna, Austria). The intensity of the BDNF probes localized on the sections was then evaluated using HistoQuest ${ }^{\circledR}$ (TissueGnostics) software. Utilization of this software allows for an objective evaluation of the localized probes and is advantageous over a subjective assessment by the investigator. Nine fetal inner ears of different gestational ages were utilized for the BDNF mRNA quantification study. A list of the specimens and sections used is included in Table 3.

\section{Results}

\section{Chromogenic BDNF mRNA in situ hybridization (ISH)}

To analyze BDNF expression during inner ear development, we particularly focused on the sensory epithelia of the cochlea and vestibular organ from GW 9-12. At GW 9, a strong BDNF signal throughout the whole epithelium was present in both the cochlea and the vestibular organ (Fig. 1a) but these labeling patterns altered during advancing development. In addition, the staining intensity appeared to decline throughout development and therefore a quantitative analysis was performed (see below).

At GW 10 and 11, in the cochlea BDNF expression was seen in the sensory epithelium (Fig. 1a, c). At GW 12 , it was restricted to certain areas and BDNF 

inner ear at GW 12. a BDNF expression (blue) is visible in a few nerve cells of the vestibular ganglion (arrow, $V G$ ). b In the control section only nuclear fast red counterstaining was observed in the vestibular ganglion. $\mathbf{c}$ Double staining of Myosin VIIA (blue). The brown staining is present in the inner and outer hair cells (black arrows), whereas the blue staining is restricted to the supporting cells (white arrows). d Control section. Positive myosin VIIA labeling (brown) is present in the inner and outer hair cells (black arrows). The sense probe revealed no labeling. Scale bars (a, b) $10 \mu \mathrm{m},(\mathbf{c}, \mathbf{d}) 5 \mu \mathrm{m}$
Fig. 3 Sections of the developing IHC (brown) and BDNF ISH
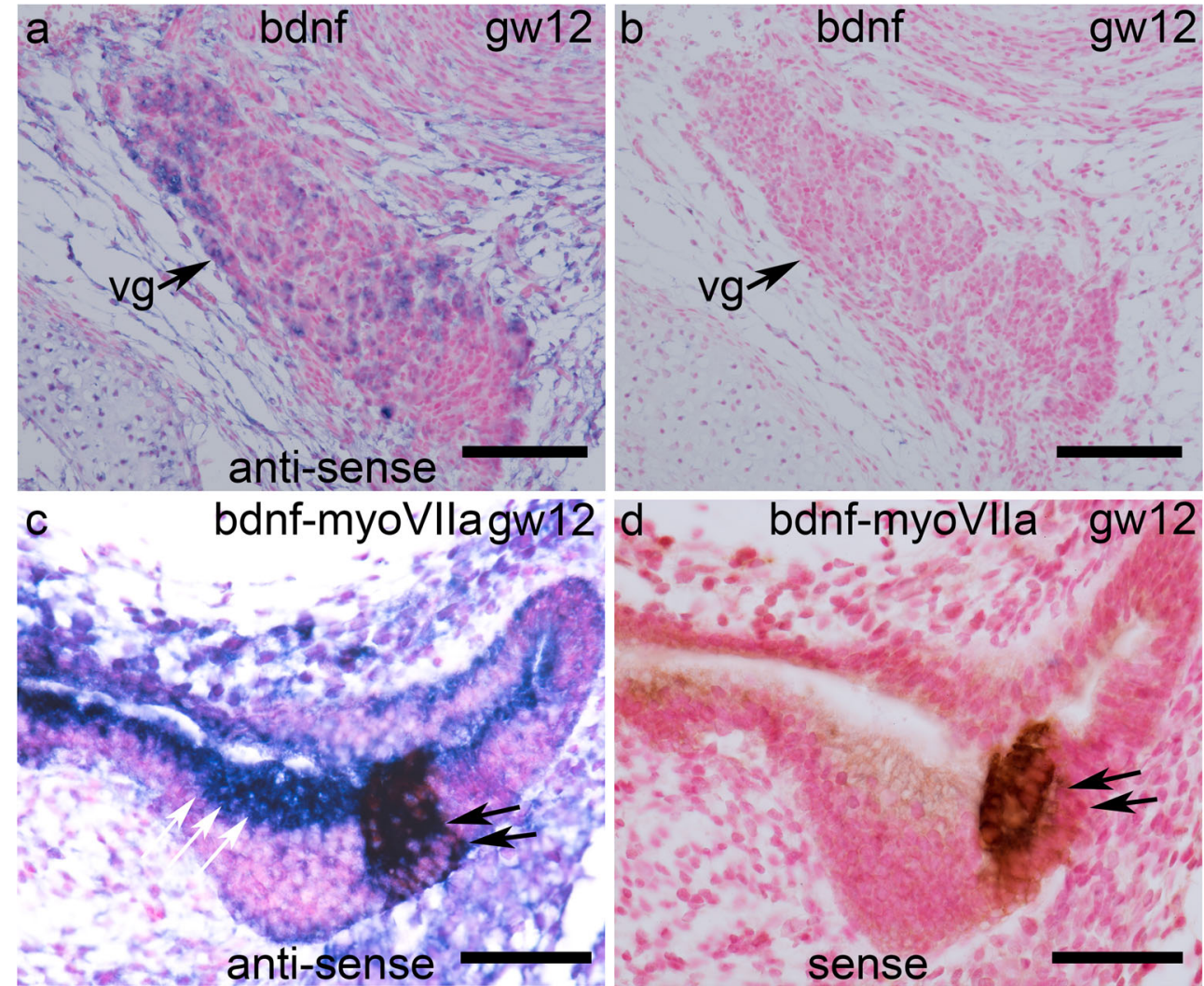

Fig. 4 Double labeling of the fetal human utricle at GW 11 using BDNF FISH and Myosin VIIa fluorescence IHC. a BDNF (red) is bound prominently to the hair cells of the extra-striolar region. b DAPI (blue) is apparent in the nuclei, while in (c), Myosin VIIa (green) labels the hair cells. d Merged image of Myosin VIIa and BDNF colocalization results in a yellow signal. Scale bars (ad) $100 \mu \mathrm{m}$

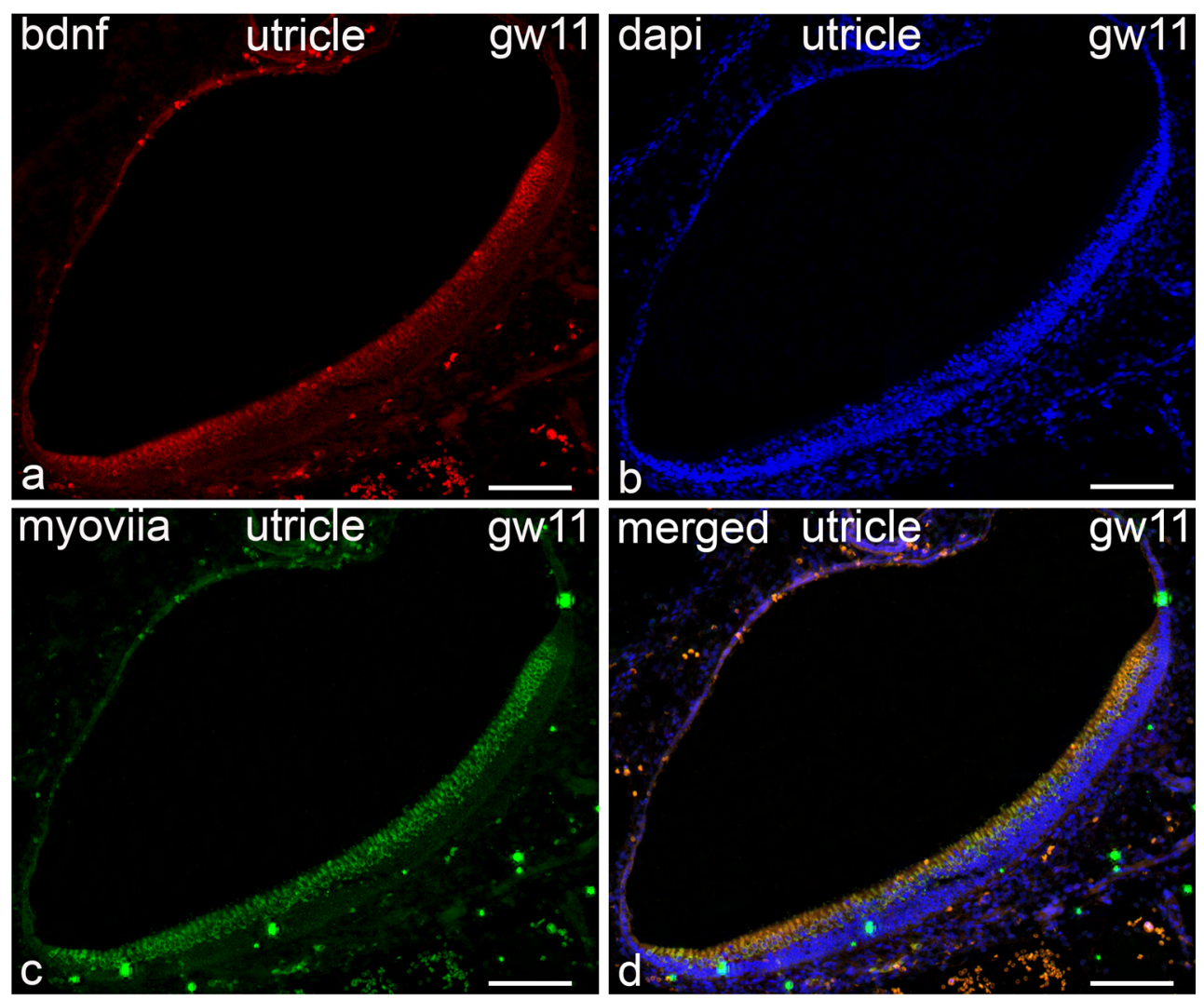


Fig. 5 Double labeling of the adult human utricle using BDNF FISH and Myosin VIIa fluorescence IHC. a BDNF (red) is bound only to the apical portion of all vestibular hair cells. b DAPI (blue) shows the nuclei, while in (c), Myosin VIIa (green) antibody labels the entire hair cells. $d$ Merged image of Myosin VIIa and BDNF colocalization results in a yellow signal but only in the apical portion of the vestibular hair cells. Scale bars $(\mathbf{a}-\mathbf{d}) 50 \mu \mathrm{m}$

Fig. 6 Double labeling of the adult human cochlea using BDNF FISH and Myosin VIIa

fluorescence IHC. a BDNF (red) is bound only to the apical portion of the hair cells. b DAPI (blue) is apparent in the nuclei, while in (c), Myosin VIIa (green) antibody labeling is limited to the cochlear hair cells. d Merged image of Myosin VIIa and BDNF

colocalization results in a yellow signal in the apical portion of the cochlear hair cells and in the Hensen's cells. Scale bar $(\mathbf{a}-\mathbf{c})$ $50 \mu \mathrm{m}$, (d) $100 \mu \mathrm{m}$
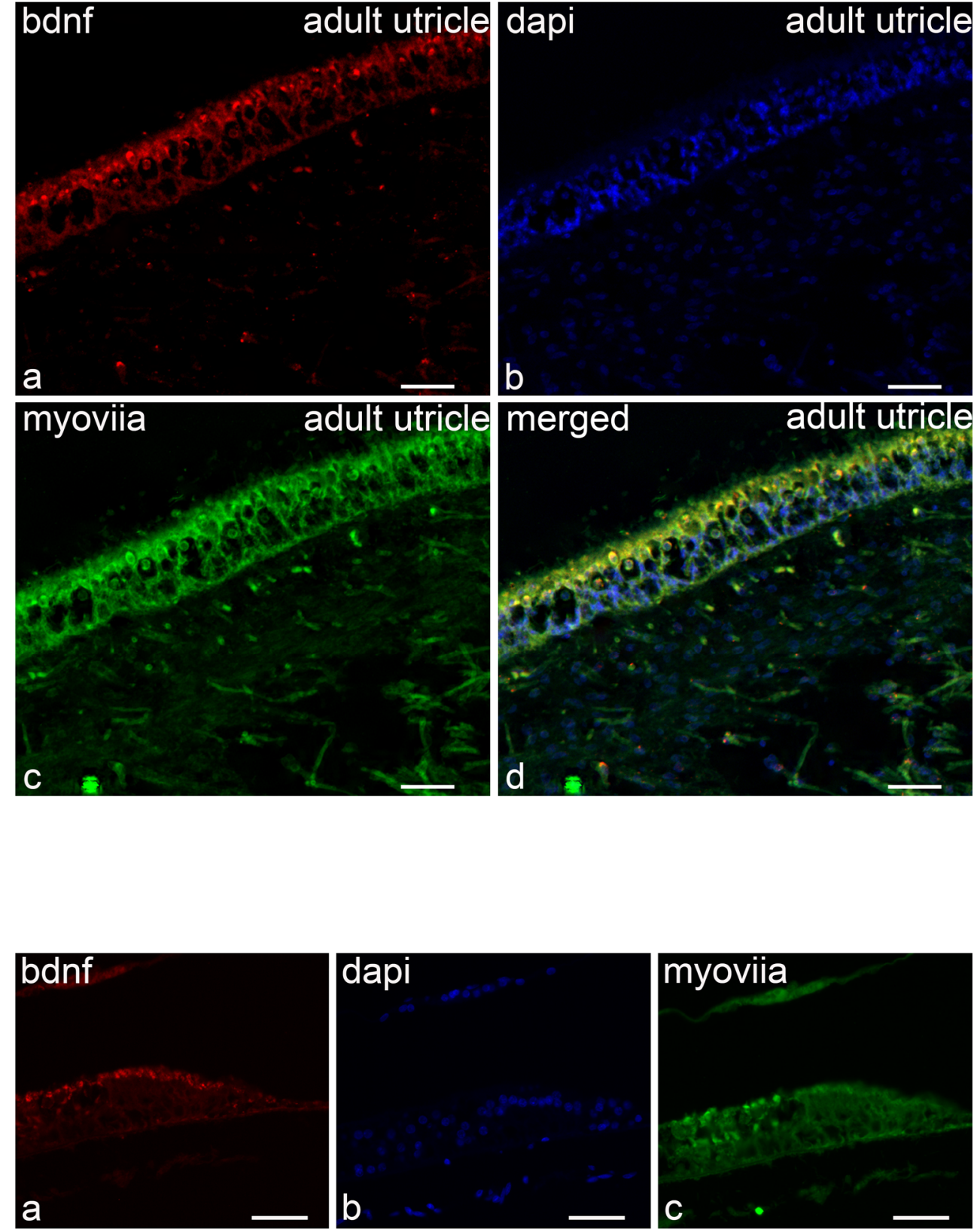

merged dult cochlea mid modiolar

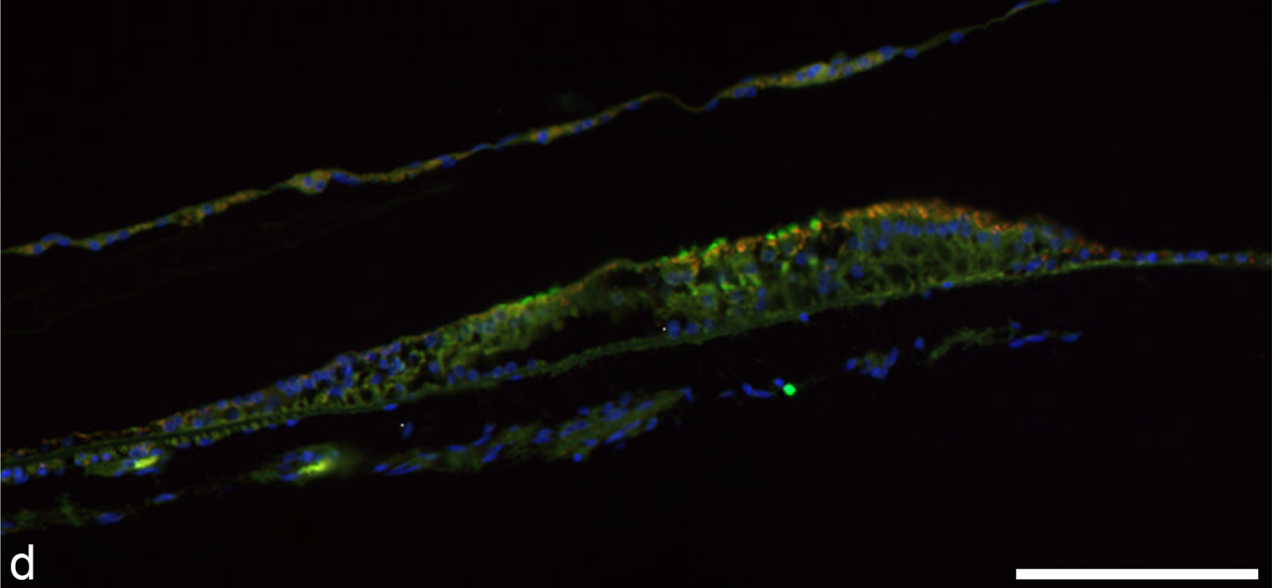




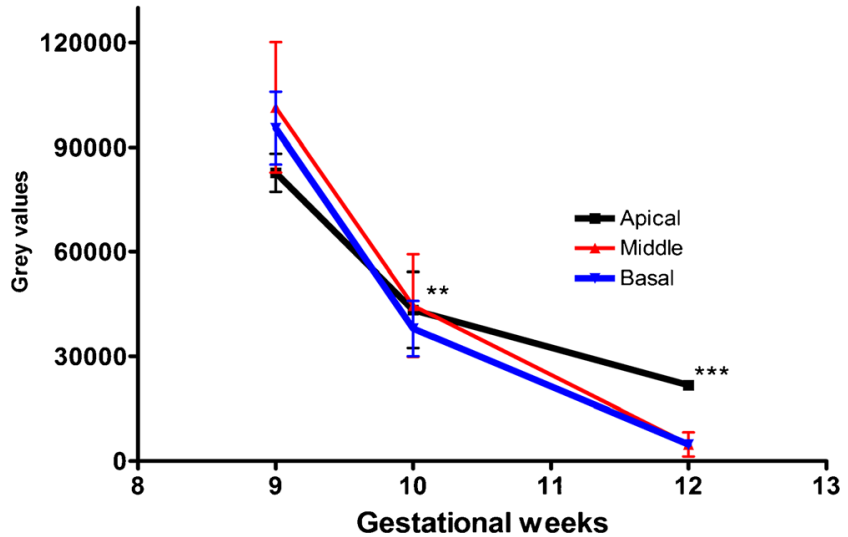

Fig. 7 Quantitative analysis of BDNF expression from ISH sections of the fetal cochlea. A declining trend in BDNF expression with progression of gestation was evident. BDNF expression intensity is measured across manually segmented regions of interest from apex to base in the sensory epithelia of the cochlea as greyscale values. The $X$-axis depicts the progression in gestational age from GW 9 to 12 and the $Y$-axis depicts the greyscale values

expression was only visible in the supporting cells of the basal turns (Fig. 1g). From GW 10 to 11, in the vestibular organ BNDF was found first in the entire utricular sensory epithelium but at GW 12 it was restricted to the extrastriolar region (Fig. 1e, g). At GW 9 and 10, in the spiral ganglia BDNF was strongly expressed in their neurons and satellite glial cells but it decreased during advancing development (Fig. 1c inset). At GW 9 and 10, in the vestibular ganglia a strong staining for BNDF was present in numerous nerve cells but at GW 12 only a few nerve cells stained (Figs. 1A and $3 \mathrm{~A}$ ). For each developmental stage, we used adjacent sections as controls. They were hybridized with the sense probes and showed no staining (Figs. 1b, d, f, h, $3 b)$.

ISH did not enable us to differentiate between the hair and supporting cells of the cochlea and vestibular organ. Thus, immunohistochemistry was used to distinguish between these two cell types.

\section{Chromogenic BDNF mRNA ISH and myosin VIIa immunohistochemistry (IHC)}

We only examined the cochlea at GW 10, when the hair cells started to develop and used the established marker, Myosin VIIa, to identify these cells (Hasson et al. 1997). We also used neighboring sections, on one of which we performed ISH whereas on the other it was IHC.

In the cochlea, Myosin VIIa was located in one hair cell, whereas the others did not stain because they were not fully developed at this time (Fig. 2a). BDNF expression was strong in the following section and was detected in the apical and basal portion of the sensory epithelium (compare Fig. 2b with 1c). No staining was observed in the control incubated with the sense probe (Fig. 2c).

We next performed double staining (BDNF mRNA ISH and myosin VIIa immunohistochemistry IHC) in order to show where exactly BDNF expression occurred. Our results provided evidence that BDNF was solely expressed in the supporting cells but not in the hair cells (Fig. 3c). The following section was used as a control. It was incubated with the sense probe and subsequently subjected to IHC. As expected, only the hair cells stained (Fig. 3d).

\section{Immunofluorescence of BDNF mRNA ISH and Myosin VIIa IHC}

We used FISH and fluorescence IHC double labeling as an additional method and compared these results with our data. We not only investigated GW 9-12 but also adult specimens to examine whether or not BDNF expression altered.

From GW 9 to 11, identical expression patterns compared with those obtained from chromogenic ISH were observed in the vestibular organ but at GW 12 the hair cells of the extrastriolar region showed a stronger signal compared to chromogenic ISH (compare Fig. 1e with 4a). Furthermore, Myosin VIIa immunohistochemistry revealed that all hair cells of the utricle sensory epithelium labeled (Fig. 4b-d).

In the adult utricle, BDNF expression was present only in the apical portion of the hair cells, whereas Myosin VIIa was observed in all portions of those cells (Fig. 5a-d).

In the adult cochlea, BDNF expression was found in both the hair and supporting cells, whereas Myosin VIIa was only located in the hair cells. In the merged figure, an intense colocalization of BDNF and Myosin VIIa was apparent only in the apical portion of the hair cells, while the supporting cells were only positive for BDNF (Fig. 6a-d).

\section{Quantitative analysis of BDNF expression obtained from sections of the cochlea (GW 9-12)}

Our results show that the staining intensity in all turns declines throughout development but a statistically significant gradient in BDNF expression from the apical to the basal turn or vice versa could not be observed. Antisense probe localization was measured as gray values from manually assigned regions of interest of the cochlear sensory epithelium (Fig. 7).

We also investigated NGF and NT3 expression in the fetal samples but unfortunately we obtained no 
convincing results from our experiments. In mammals, it is suggested that the receptors for BDNF, NGF and NT3, namely p75NTR, TrkA, B and C are upregulated during embryonic development (Huang and Reichardt 2001). Therefore, we investigated whether these receptors were present or not between GW 9 and 12 .

\section{IHC for p75NTR and Trk receptors}

\section{GW 9}

In the vestibular organ, p75NTR-stained nerve fibers were observed below the cristae where some of them inserted into the sensory epithelium and proceeded up to its apical portion (Fig. 8A). A similar staining pattern was seen in the saccule (Fig. 8B). The cochlea remained unstained but below its lower basal turn a few spiral ganglia were positive for p75NTR (Fig. $8 \mathrm{C})$.

The vestibular organ, the cochlea and the spiral as well as the vestibular ganglia exhibited no staining for TrkA, B (Fig. 8d) and C. In the vestibular nerve a weak staining but only for TrkC, was visible (Fig. 8e).

\section{GW 10 and 11}

At this time, p75NTR positive nerve fibers could be observed within and below the cochlea and in the spiral ganglia (Fig. 9a). Likewise, TrkB and TrkC staining was detected in the spiral ganglia but their nerve fibers did not insert into the epithelium (Fig. 9c, e).

In the vestibular organ, the hair and supporting cells of the striolar region as well as the mesenchyme displayed positive p75NTR immunostaining (Fig. 9g). In addition, it appeared that more p75NTR positive nerve fibers inserted into the epithelium of the crista ampullaris compared with GW 9 (Fig. 9b). A weak TrkB staining was visible in a few nerve fibers inserting into the utricle and below it (Fig. 9d). The vestibular ganglia showed no staining for p75NTR and TrkB (data not shown). TrkC was located in these ganglia but the nerve fibers did not insert into the sensory epithelium of the utricle (Fig. 9f).

The vestibular organ, the cochlea and the spiral as well as the vestibular ganglia displayed no staining for the TrkA but the facial nerve as well as the intermediate nerve of the inner acoustic meatus showed a positive staining (Fig. 9h).
Fig. 8 Immunostained sections of the developing inner ear during GW 9. a Intense p75NTR staining (brown) is apparent in the nerve fibers underlying the fetal crista. The arrows indicate the nerve fibers that insert into the epithelium reaching its apical portion. b p75NTR immunoreactivity is visible in the nerve fibers underlying the saccule. Several immunostained nerve fibers insert into the epithelium and reach the basal portion of the hair cells. The hair cells are encircled. $\mathbf{c}$ p 75NTR localization is only seen in the ganglion cells (arrows) below the lower basal turn $(l b t)$ of the cochlea. d TrkB expression is absent in the fetal inner ear during GW 9. e TrkC expression is apparent only in the vestibular nerve (vest. $n$ ). Scale bars (a, b) $2 \mu \mathrm{m},(\mathbf{c}, \mathbf{d}) 5 \mu \mathrm{m},(\mathbf{e})$ $10 \mu \mathrm{m} . c$ crista ampullaris, $s$ saccule, $u$ utricle, $l b t$ lower basal turn. The sections are counterstained with hematoxylin

\section{GW 12}

In the cochlea, a distinct staining for p75NTR was observed in the inner pillar cells and the nerve fibers below (Fig. 10a). Furthermore, the inner hair cells exhibited a distinct immunostaining for TrkB that was not seen before. No staining was seen in the outer hair cells (Fig. 10c). Immunoreactivity for TrkC had altered at this time compared with previous stages. A strong staining was now present in the nerve fibers below the inner and outer hair cells (Fig. 10e). In the spiral ganglia the staining pattern for p75NTR, TrkB and TrkC was similar to that of GW 10 and 11 (data not shown).

In the vestibular organ, the staining pattern was similar to that of GW 10 and 11 (data not shown). In the vestibular ganglia, a strong staining for p75NTR was visible in the Schwann cells and the nerve fibers (Fig. 10b). Furthermore, the nerve cells, their fibers and the future satellite glial cells labeled for TrkB and TrkC (Fig. 10d, f).

We did not find TrkA staining at this developmental stage.

\section{Discussion}

Our results show that, in human fetuses, BDNF expression declined in the cochlea. In all turns of the cochlea, it was highest in GW 9, then decreased and was lowest in GW 12. Apart from this, BDNF expression was restricted to certain areas as development progressed and was exclusively observed in the supporting cells at GW 12. In the adult cochlea, however, BDNF expression was observed in both the hair and supporting cells. In the vestibular organ, BDNF was first noted in the entire utricular epithelium but at GW 12 it could only be detected in the extrastriolar regions. In adults, BDNF was only present in the apical portion of the hair cells. From the neurotrophic 


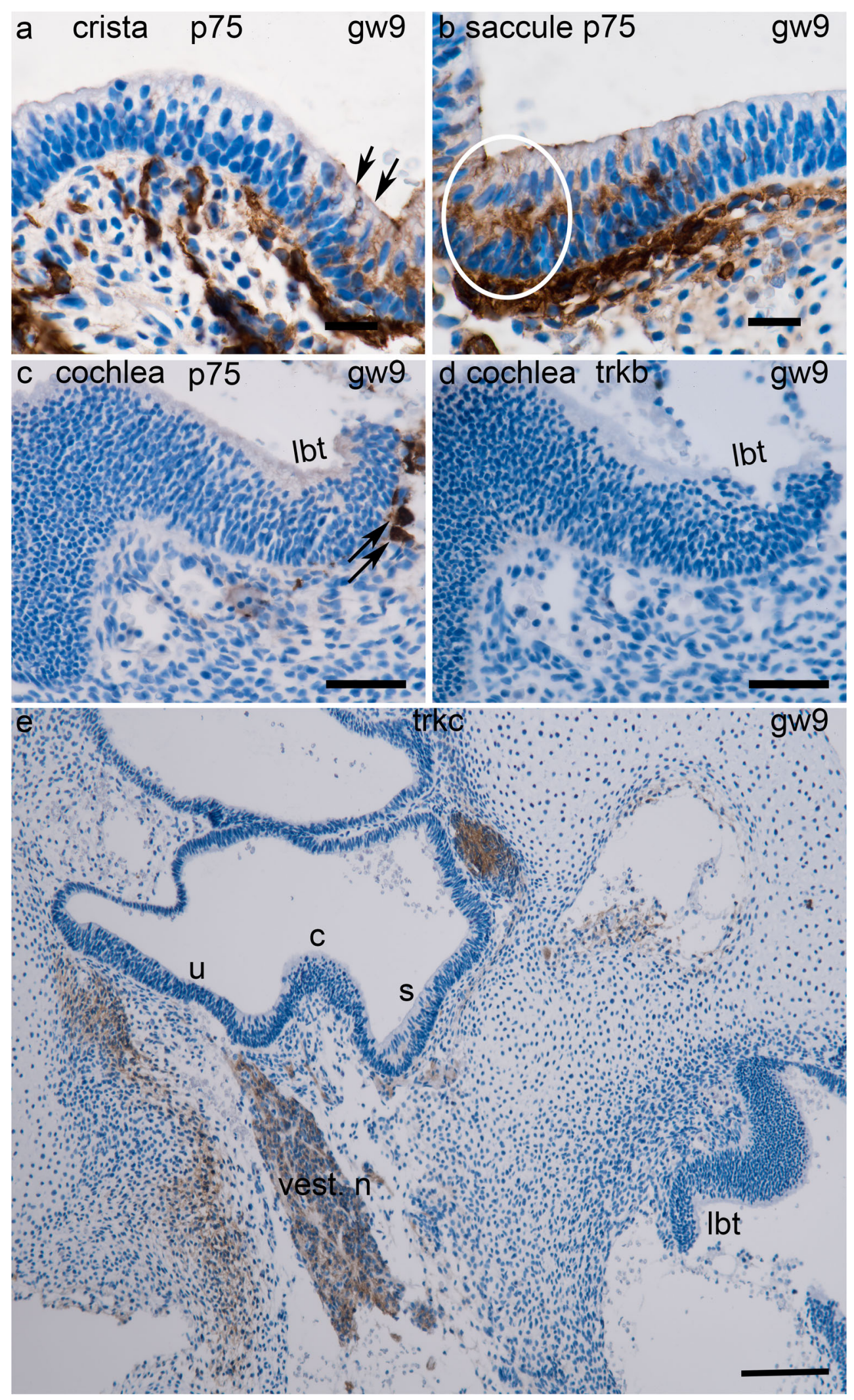


receptors, p75NTR was found in the inner pillar cells, TrkB in the inner hair cells and TrkC in both the inner and outer hair cells.

The spatio-temporal (from the apical to the basal turn of the cochlea during development) gradient in BDNF expression, evident in the embryonic cochlea of mice (Fritzsch et al. 2004), could not be noticed in the fetal human cochlea. One reason could be that murine developmental models with a spatio-temporal pattern of BDNF expression in the cochlea cannot be compared with the human inner ear development. In rodents, the developmental timeline of the inner ear is considerably shorter than in humans and also the lifespan is much shorter in rodents. Furthermore, the functional characteristics in the human fetal cochlea are achieved by GW 19 (Hepper and Shahidullah 1994) and in the vestibulum by GW 18 (Lim et al. 2014), while in mice the inner ear function is completed not before day 15 after birth. This important aspect should be considered in future studies. Another reason could be that in our study only a small sample size and a limited number of distinct regions (e.g., the apical turn of the cochlea was only present in one section at GW 12) was examined and thus classical statistical tools could not be applied. Nonetheless, our data provide evidence that there is a only time-dependent decline in BDNF expression as gestational age progresses. Earlier research from our group using fetal human cochleae showed BDNF immuno-staining at GW 12 but not in previous stages (Pechriggl et al. 2015). In addition, BDNF localization was not observed in immuno-stained cochlear sections from human adults (Liu et al. 2011). These findings are not in line with our present data, where ISH clearly demonstrated BDNF expression in both fetuses (GW 9-12) and adults. One explanation for these differences could be that different techniques were used and that ISH revealed a higher sensitivity compared with IHC (Kim et al. 2009). The continuous expression of BDNF in the cochlea indicates its potential role for the long-term survival of hair cells and hearing functionality (Leake et al. 2011) as observed in cat spiral ganglia.

Staining for p75NTR is present as early as GW 5 in the human fetal cochleo-vestibular ganglion (Vega et al. 1999) and also among the peripheral processes of the human fetal cochlea at GW 9 (Locher et al. 2014). In the present study, immuno-staining for this receptor was seen from GW 9 onwards and finally extended as far as the inner pillar cells at GW 12. The expression for p75NTR was intense in the utricule and saccule where the staining for this receptor was apparent at the basal portion of the maturing vestibular cells.
Fig. 9 Immunostained sections of the developing inner ear during GW 10 to 11 . a p75NTR expression (brown) is visible in the nerve fibers of the maturing cochlea and the spiral ganglia (arrow, spg). b p75NTR expression is seen in the nerve fibers of the crista ampullaris and below it. c TrkB expression is apparent in the nerve fibers and surrounding glial cells of the spiral ganglion (arrow, spg). d Weak TrkB staining is visible in the nerve fibers underlying and entering the utricle (arrows). e TrkC localization is limited to the spiral ganglion (arrow, spg). f TrkC expression is observed in the vestibular ganglia $(V G)$. g p75NTR staining is apparent in the striolar region of the saccule and underlying mesenchyme. $\mathbf{h}$ TrkA staining is only apparent in the facial nerve ( $n$. facialis) and the intermediate nerve (n. intermedius) of the developing inner ear at GW 10. Scale bars (a, c, e, g) $10 \mu \mathrm{m}$, (b, d) $5 \mu \mathrm{m}$, (f) $15 \mu \mathrm{m}$, (h) $30 \mu \mathrm{m}$. $m t$ middle turn, $u$ utricle, $c$ crista ampullaris. The sections are counterstained with hematoxylin

Our results show that TrkB and TrkC expression in the developing human inner ear was observed from GW 10 onwards and was later upregulated in the inner hair cells being innervated by GW 12. TrkB expression was also evident in the spiral ganglion cells of the developing inner ear at GW 11. This finding parallels previous immuno-histochemical examinations of adult human cochleae revealing TrkB expression being localized in spiral ganglion neurons (Liu et al. 2011).

During human fetal inner ear development, BDNF expression declines while p75NTR, TrkB and TrkC are upregulated. Trophic support for inner ear sensory afferent neurons is provided solely by BDNF and NT-3 and their receptors TrkB and TrkC in mice (Fritzsch et al. 2004). The time period corresponding to BDNF expression that we examined (GW 9-12) closely matches the onset of sensory neuronal innervation in the fetal human inner ear (Johnson Chacko et al. 2016). The reduction in BDNF expression in the course of development might give preference to neurotrophin delivery from supporting cells to the sensory neurons as shown in inner ear hair cells of murines following BDNF withdrawal (Kersigo and Fritzsch 2015). The elevated levels of TrkB, TrkC and p75NTR could be significant in ensuring the survival of maturing inner ear neurons. TrkB could also be critical for a later rearrangement of innervation as observed in murines (Knipper et al. 1996), while both TrkC and TrkB upregulation could be significant in the normal development of the afferent innervation processes as observed in murines (Fritzsch et al. 1999).

In sum, our findings suggest that BDNF and neurotrophin receptors are important players during early human inner ear development. In particular, they seem to be important for the survival of the afferent sensory neurons. However, further studies will be 


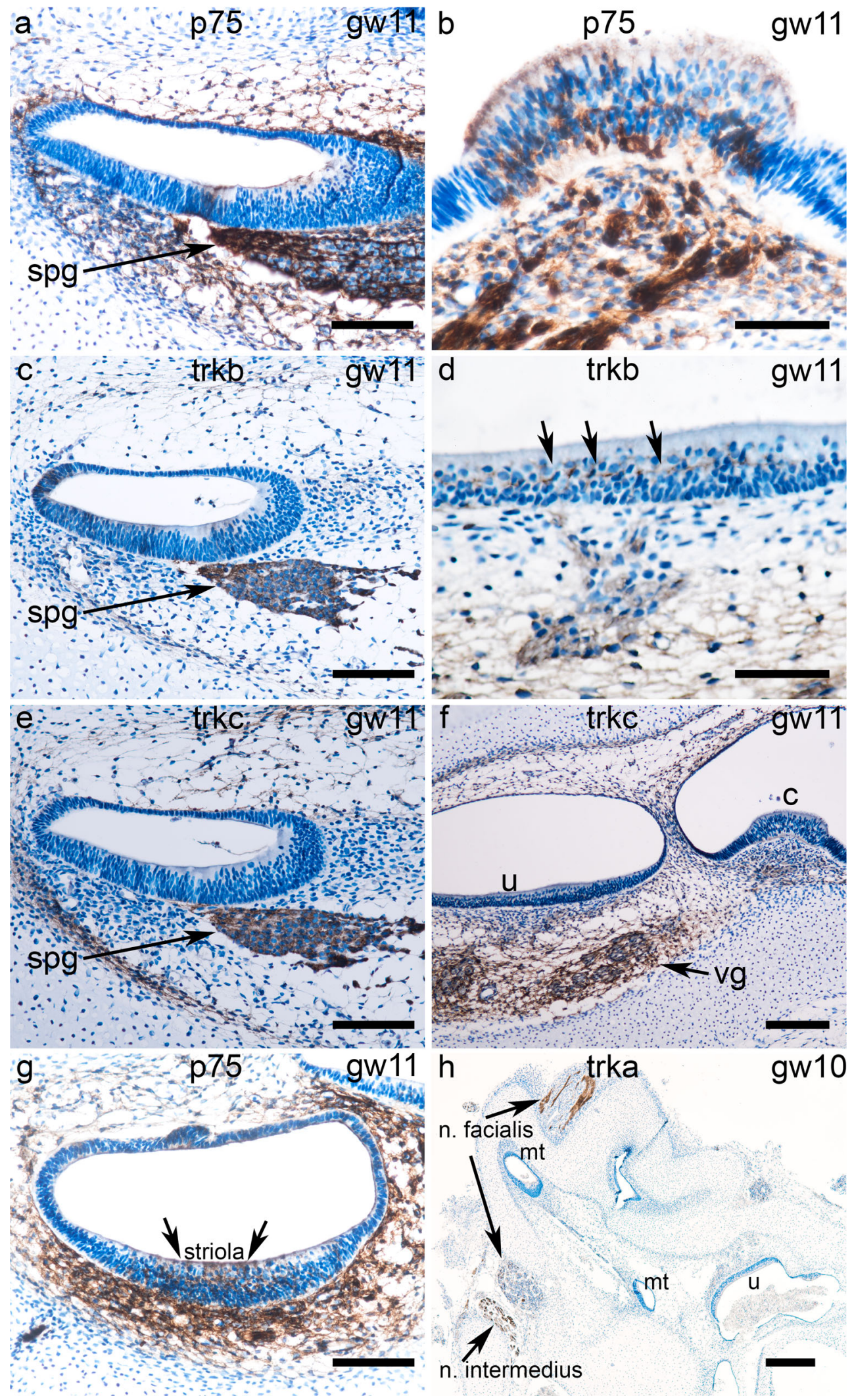


Fig. 10 Immunostained sections of the developing inner ear during GW 12. a p75NTR staining (brown) is seen in the inner pillar (ip) cells and nerve fibers below in the cochlea. b p75NTR staining is present in the Schwann cells (black arrow) and nerve fibers (white arrow) of the vestibular ganglia. c TrkB staining is present in the inner hair cells $(i h c)$ of the cochlea. The outer hair cells $(o h c)$ display no staining. d TrkB immunostaining is apparent in the nerve cells (black arrows), their fibers and future satellite glial cells of the vestibular ganglia e. TrkC immunostaining is present in the nerve fibers (black arrow) that insert into the epithelium and terminate below the inner $(i h c)$ and outer hair cells $(o h c)$ f. TrkC immunostaining is apparent in the nerve cells (black arrows), their fibers and future satellite glial cells of the vestibular ganglia. Scale bars $(\mathbf{a}-\mathbf{f}) 2 \mu \mathrm{m}$. The sections are counterstained with hematoxylin
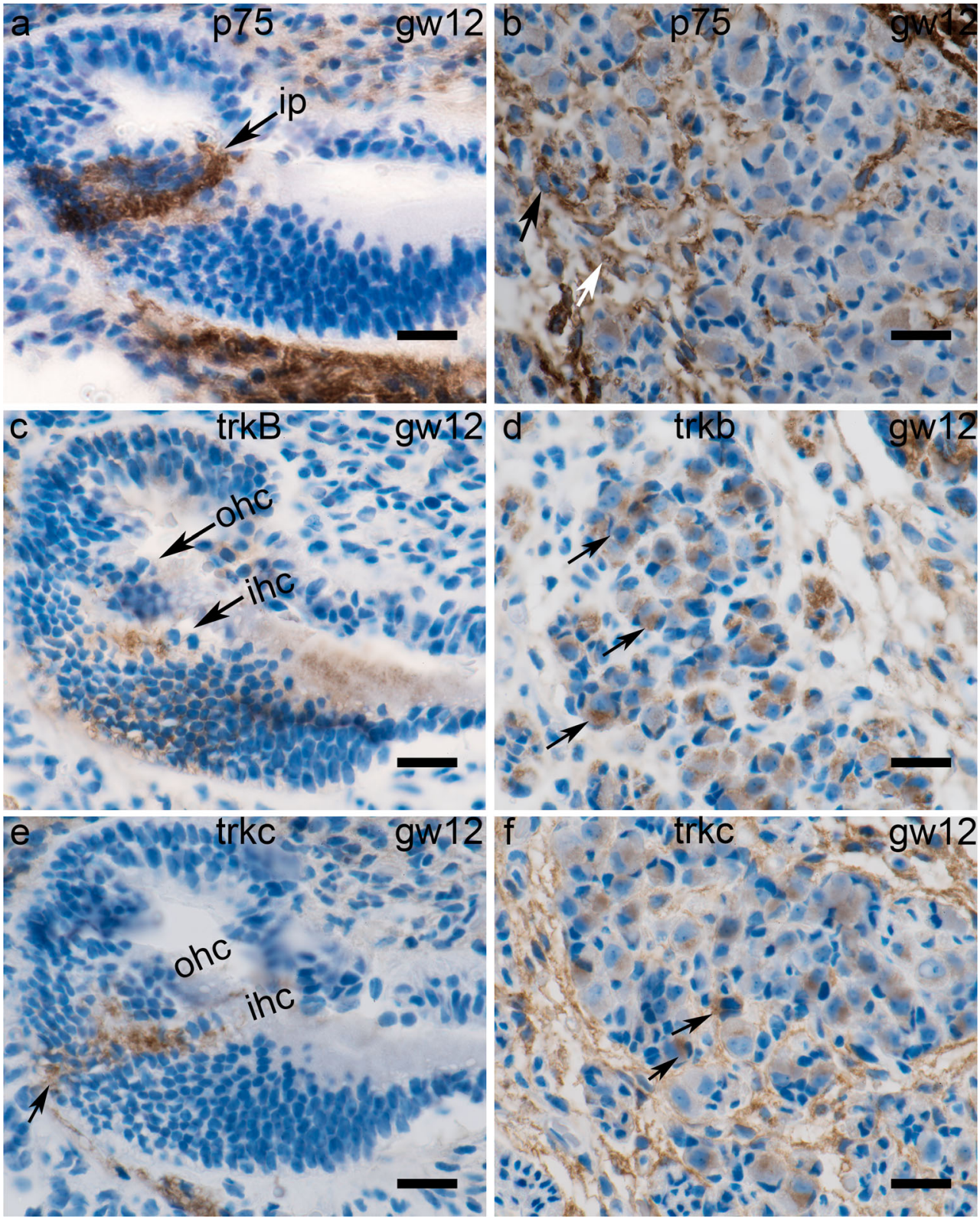

required to show which molecules are important in order to establish the innervation of the hair cells.

Acknowledgements Open access funding provided by the University of Innsbruck and Medical University of Innsbruck. We thank the Ostereichische National Bank Anniversary Fonds Project 15607 and Tiroler Landesregierung for funding us through the K-Regio project VAMEL (Vestibular Anatomy Modeling \& Electrode Design). This study was also supported by research of the European Community Research; Human stem cell applications for the treatment of hearing loss. Grant Agreement No. 603029. Project acronym; OTOSTEM (HRA). Contract grant sponsor: Austrian Science Foundation (FWF); Contract grant number: P21848-N13. The excellent support of Dr. H. Wolf and his team in the conservation of the human samples is gratefully acknowledged. Also, we would like to thank Annabella Knab for her excellent work with the tissue sectioning and Claudia Simon for correcting the manuscript. We are also grateful to MED-EL GmbH for funding this research.

\section{Compliance with ethical standards}

Conflict of interest The authors declare that they have no conflict of interest.

Open Access This article is distributed under the terms of the Creative Commons Attribution 4.0 International License (http:// creativecommons.org/licenses/by/4.0/), which permits unrestricted use, distribution, and reproduction in any medium, provided you give appropriate credit to the original author(s) and the source, provide a link to the Creative Commons license, and indicate if changes were made.

\section{References}

Agerman K, Hjerling-Leffler J, Blanchard MP, Scarfone E, Canlon B, Nosrat C, Ernfors P (2003) BDNF gene replacement reveals multiple mechanisms for establishing neurotrophin specificity during sensory nervous system development. Development 130:1479-1491 
Bianchi LM, Conover JC, Fritzsch B, DeChiara T, Lindsay RM, Yancopoulos GD (1996) Degeneration of vestibular neurons in late embryogenesis of both heterozygous and homozygous BDNF null mutant mice. Development 122:1965-1973

Bitsche M, Dudas J, Roy S, Potrusil T, Schmutzhard J, Schrott-Fischer A (2011) Neurotrophic receptors as potential therapy targets in postnatal development, in adult, and in hearing loss-affected inner ear. Otol Neurotol 32:761-773

Ernfors P, Lee KF, Jaenisch R (1994) Mice lacking brain-derived neurotrophic factor develop with sensory deficits. Nature 368:147-150

Ernfors P, Van De Water T, Loring J, Jaenisch R (1995) Complementary roles of BDNF and NT-3 in vestibular and auditory development. Neuron 14:1153-1164

Fritzsch B, Pirvola U, Ylikoski J (1999) Making and breaking the innervation of the ear: neurotrophic support during ear development and its clinical implications. Cell Tissue Res 295:369-382

Fritzsch B1, Fariñas I, Reichardt LF. (1997a) Lack of neurotrophin 3 causes losses of both classes of spiral ganglion neurons in the cochlea in a region-specific fashion. J Neurosci 17(16):6213-25

Fritzsch B, Silos-Santiago I, Bianchi LM, Fariñas I (1997b) The role of neurotrophic factors in regulating the development of inner ear innervation. Trend Neurosci 20(4):159-64

Fritzsch B, Tessarollo L, Coppola E, Reichardt LF (2004) Neurotrophins in the ear: their roles in sensory neuron survival and fiber guidance. Prog Brain Res 146:265-278

Fukui H, Wong HT, Beyer LA, Case BG, Swiderski DL, Di Polo A, Ryan AF, Raphael Y (2012) BDNF gene therapy induces auditory nerve survival and fiber sprouting in deaf Pou4f3 mutant mice. Sci REp. 2: $838 \mathrm{https}: / /$ doi.org/10.1038/srep00838

Hallbook F, Fritzsch B (1997) Distribution of BDNF and trkB mRNA in the otic region of 3.5 and 4.5 day chick embryos as revealed with a combination of in situ hybridization and tract tracing. Int J Dev Biol 41:725-732

Hasson T, Gillespie PG, Garcia JA, MacDonald RB, Zhao Y, Yee AG, Mooseker MS, Corey DP (1997) Unconventional myosins in innerear sensory epithelia. J Cell Biol 137:1287-1307

Hepper PG, Shahidullah BS (1994) Development of fetal hearing.Arch Dis Child Fetal Neonatal Ed 71(2):F81-F87

Huang EJ, Reichardt LF (2001) Neurotrophins: roles in neuronal development and function. Annu Rev Neurosci 24:677-736

Huang EJ, Reichardt LF (2003) Trk receptors: roles in neuronal signal transduction. Annu Rev Biochem 72:609-642

Inoue A, Iwasaki S, Fujimoto C, Nakajima T, Yamasoba T (2014) Developmental changes in the protective effect of exogenous brain-derived neurotrophic factor and neurotrophin-3 against ototoxic drugs in cultured rat vestibular ganglion neurons. Cell Tissue Res 356:299-308

Johnson Chacko L, Pechriggl EJ, Fritsch H, Rask-Andersen H, Blumer MJ, Schrott-Fischer A, Glueckert R (2016) Neurosensory differentiation and innervation patterning in the human fetal vestibular end organs between the gestational weeks 8-12. Front Neuroanat 10:111

Kersigo J, Fritzsch B (2015) Inner ear hair cells deteriorate in mice engineered to have no or diminished innervation. Front Aging Neurosci 7:33
Kim D, Ha Y, Lee YH, Chae S, Lee K, Han K, Kim J, Lee JH, Kim SH, Hwang KK, Chae C (2009) Comparative study of in situ hybridization and immunohistochemistry for the detection of porcine circovirus 2 in formalin-fixed, paraffin-embedded tissues. J Vet Med Sci 7(7):1001-4

Knipper M, Zimmermann U, Rohbock K, Kopschall I, Zenner HP (1996) Expression of neurotrophin receptor trkB in rat cochlear hair cells at time of rearrangement of innervation. Cell Tissue Res 283:339-353

Leake PA, Hradek GT, Hetherington AM, Stakhovskaya O (2011) Brainderived neurotrophic factor promotes coch-lear spiral ganglion cell survival and function in deafened, developing cats. J Comp Neurol 519:1526-1545

Li Y, Zhang SF, Zou SE, Xia X, Bao L (2011) Accumulation of nerve growth factor and its receptors in the uterus and dorsal root ganglia in a mouse model of adenomyosis. Reprod Biol Endocrinol 9:30

Lim R, Drury HR, Camp AJ, Tadros MA, Callister RJ, Brichta AM (2014) Preliminary characterization of voltage-activated whole-cell currents in developing humanvestibular hair cells and calyx afferent terminals. J Assoc Res Otolaryngol. 15(5):755-66 https://doi.org/ 10.1007/s10162-014-0471-y

Liu W, Kinnefors A, Bostrom M, Rask-Andersen H (2011) Expression of TrkB and BDNF in human cochlea-an immunohistochemical study. Cell Tissue Res 345:213-221

Locher H, de Groot JC, van Iperen L, Huisman MA, Frijns JH, de Sousa Lopes CSM (2014) Distribution and development of peripheral glial cells in the human fetal cochlea. PLoS ONE 9:e88066

Pechriggl EJ, Bitsche M, Glueckert R, Rask-Andersen H, Blumer MJ, Schrott-Fischer A, et al. (2015) Development of the innervation of the human inner ear. Dev Neurobiol 75, 683-702

Popper P, Lopez I, Beizai P, Li G, Kim J, Micevych PE, Honrubia V (1999) Expression of BDNF and TrkB mRNAs in the crista neurosensory epithelium and vestibular ganglia following ototoxic damage. Brain Res 846:40-51

Schimmang T, Tan J, Muller M, Zimmermann U, Rohbock K, Kopschall I,Limberger A, Minichiello L, Knipper M (2003) Lack of Bdnf and TrkBsignalling in the postnatal cochlea leads to a spatial reshaping ofinnervation along the tonotopic axis and hearing loss. Development130:4741-4750

Soni LE, Warren CM, Bucci C, Orten DJ, Hasson T (2005) The unconventional myosin-VIIa associates with lysosomes. Cell Motil Cytoskeleton 62:13-26

Vazquez E, San Jose I, Naves J, Vega JA, Represa J (1996) p75 and Trk oncoproteins expression is developmentally regulated in the inner ear of human embryos. Int J Dev Biol Suppl 1:77S-78S

Vega JA, San Jose I, Cabo R, Rodriguez S, Represa J (1999) Trks and p75 genes are differentially expressed in the inner ear of human embryos. What may Trks and p75 null mutant mice suggest on human development? Neurosci Lett 272:103-106

Whitfield TT (2015) Development of the inner ear. Curr Opin Genet Dev 32:112-118

Wu DK, Kelley MW (2012) Molecular mechanisms of inner ear development. Cold Spring Harb Perspect Biol 4:a008409 